\title{
How Mechanical Bund Formation Affects the Shear Strength of Bunds: A Study in Paddy Wetlands
}

\author{
Suma Nair ${ }^{1 *}$ and V.R. Ramachandran ${ }^{2}$ \\ ${ }^{1}$ Department of FPME, KCAET \& Asst. Prof., KVK, Thrissur, Kerala, India \\ ${ }^{2}$ (FPME), KAU, Vellanikkara, Thrissur, Kerala, India \\ *Corresponding author
}

\section{A B S T R A C T}

\section{Keywords \\ Mechanical bund \\ formation, Shear strength, Paddy wetlands \\ Article Info \\ Accepted: \\ 04 October 2018 \\ Available Online: \\ 10 November 2018}

Bund formation is an important field preparation operation in rice cultivation. Presently, this operation is done manually. A low cost, tractor drawn bund forming and strengthening implement for paddy wetlands has been developed. Shear strength of the bunds formed is one of the parameters for assessing effectiveness of bunds. Shear strength were measured for the bunds formed using the developed tractor drawn wetland bund formers and compared with the manual bunds formed at three locations. The medium bund former was seen to impart more strength to bunds formed at Pullazhi kolepadavu. At Kolothumpadam kolepadavu, the big bund former and the combination run provide strong bunds while at Athalur fields (non kole) the mechanical formers could be used to form new bunds only.

\section{Introduction}

Bund formation is a very important part of land preparation in paddy wetlands. Kole lands are a major rice growing tract in Kerala. They extend, almost parallel to the coastline, in an area of 13,632 ha, in the Thrissur and Malappuram districts of the State. The kole lands are located $0.5 \mathrm{~m}$ to $1.0 \mathrm{~m}$ below sea level and remain submerged under water for about six months of the year from May to October. The lands are very fertile as alluvial deposits are brought into this shallow basin, mainly by the Karuvannur river and Kecheri river, which then drain out into the Arabian sea. These lands have been put under paddy cultivation since long. Though the cultivation process is tedious here, the bumper yields (that are usually double the yield from the conventional paddy lands) prompt the farmers to cultivate rice here, every year. These large extents of paddy lands are crisscrossed by canals which divide the area into smaller blocks, called kolepadavus that ease the cultivation process. Each padavu has an average area ranging from 100 ha to 200 ha. The submerged fields are dewatered, mainly using the petti and para, starting by September, and the cultural practices for rice cultivation are then started. The fields have very soft soils at this juncture, as they have remained submerged for a long time. Further the soil comprises of alluvium coming with the river/ flood waters. Hence the properties of soil in the kole lands are very typical and unique (Johnkutty and Venugopal, 1993; 
Sivaperuman and Jayson, 2000; Jayan and Sathyanathan, 2010; Leema, 2015).

Manual labour was adopted earlier for rice cultivation in the kole lands. The decline in labour availability affected the rice cultivation, and the area under rice also declined drastically from 8.82 lakh ha in 1974-75 to 1.96 lakh hectares in 2015-16, which includes the kole lands also. With the advent of mechanization and other institutional support programmes for the farmers, the rice cultivation has now been revived in the kole lands. Land preparation operations such as tillage and leveling- the most tedious operations in the kole, as the areas are submerged under water for long and have very soft soils - are now being carried out using machines like power tiller and tractor in these areas. Combine harvesters are used for harvesting the crop. These machines have addressed two major areas of manual labour requirement and hence help in continuation of rice cultivation.

However, a major operation that still involves manual labour is the formation of bunds - the outer and major bunds as well as the smaller, inner bunds that are used for water management and demarking the fields. As all the operations for rice cultivation in kole lands are strictly time bound, the timely availability of labour for bund forming is a vital requirement to complete the land preparation. Hence, the bund making or strengthening process requires machinery that is low cost and reduces operator drudgery.

A low cost bund strengthening implement has been developed at KCAET, Tavanur, for use in the kole lands of Kerala to address the scarcity of skilled labour for bund forming operation. As the sizes of bunds vary from location to location in the kole lands, three prototypes were fabricated, keeping the farmers' practices in mind. These implements are tractor drawn. These yielded bunds with the major dimensions as provided in table 1. The implement was designed to be operated by mini tractors and tractors of higher horsepower.

Shear strength is an inherent characteristic of soil which comes into play in agricultural soils especially when there is machine traffic over the soil. Shear strength permits a body of soil to remain in a slope. The efficiency with which an agricultural implements works is directly associated with the physical and mechanical properties of soil such as moisture content, soil texture, shear strength, compaction and frictional forces (Kepner et al., 1990; Roy and Das. 2014). Hence it is important to study the shear strength values of the typical soils of the kole lands, as wet soil exhibit greater changes in shear strength (O’Sullivan and Robertson, 1996).

\section{Materials and Methods}

The three models developed were tested at two locations in the kole lands (Pullazhi kolepadavu and Kolothumpadam kolepadavu) and one location in a non kole paddy wetland, using two power sources - $11.5 \mathrm{~kW}$ mini tractor and $31.32 \mathrm{~kW}$ tractor. Various parameters of the bunds formed by the various processes were assessed.

Shear strength is important in determining the sloe retention characteristic of soils. Hence when bunds are formed, the shear strength of bunds offers an indication of the strength and stability of the bund. Hence the shear strength was measured on the different types of bunds formed.

Shear strength can be determined using many different methods such as the direct shear test, triaxial compression test, unconfined compression test and vane shear test. These tests, except the vane shear test, can be performed in the laboratory. However, in this study, the shear strength measurement had to 
be done in the field. The peculiar nature of the soil hindered collection of undisturbed soil samples that are required for such laboratory tests. Also, the true condition in the field could be assessed only by in situ measurement of shear strength. Hence the shear strength of the bunds was determined in situ by using the vane shear apparatus (Tada, 1987). The peak and remoulded shear strength of the soil is determined using vane shear test. The procedure as per ASTM D2573 was followed for determining the shear strength. A fourbladed vane, with sharp tapered edges, was attached to a $12.7 \mathrm{~mm}$ diameter rod. The vane was pushed into the soil to the predetermined depth and torque was applied from the surface, at a very slow rate of 0.1 degrees per second. The torque required to be applied increased continuously, up till a maximum value and then it dropped suddenly indicating shear failure. This peak value of torque is related to the peak strength and was noted. Then the vane was quickly rotated ten times to remould the soil. The procedure of application of torque and reading the peak value was repeated and the torque was measured to obtain the remoulded soil strength.

The sensitivity was calculated as the ratio between the peak and the remoulded strength (Smith, 1996). The vane was then further advanced to the next depth of measurement and the procedures were repeated. The maximum torque measured was used to calculate the shear strength using the formula

$\mathrm{S}_{\mathrm{u}}=\frac{\mathrm{T}}{\mathrm{K}}$

Where

$\mathrm{S}_{\mathrm{u}}=$ shear strength of soil, $\mathrm{kPa}$

$\mathrm{T}=$ torque, $\mathrm{N} . \mathrm{m}$

$\mathrm{K}=$ constant, depending on dimensions of the vane $=\left(0.00000388 \mathrm{D}^{3}-0.00000076\right), \mathrm{m}^{3}$
$\mathrm{D}=$ diameter of the vane, $\mathrm{cm}$

The vane shear strength of the formed bunds was determined at three depths of $20 \mathrm{~cm}, 40$ $\mathrm{cm}$, and $60 \mathrm{~cm}$, at the three trial locations.

\section{Results and Discussion}

The shear strength values were recorded with three replications for each recording. Readings were taken on the day of bund formation, and on the third and the seventh days after bund formation. The shear strength values were computed as per the procedure explained. The readings on manually formed bunds were also taken for comparison. The data was then analysed statistically using the SPSS 16.0 software and a one factor ANOVA and the DMRT analysis was performed on the data obtained.

\section{Shear strength changes observed in bunds formed at Pullazhi kolepadavu}

The observations of shear strength, measured in situ using the vane shear test, at the three depths viz., $0.20 \mathrm{~m}, 0.40 \mathrm{~m}$ and $0.60 \mathrm{~m}$, are presented in tables 2 to 4 .

Figure 1 depicts how shear strength, measured in situ using the vane shear apparatus, varied in the different types of bunds formed at Pullazhi kole fields at consecutive time intervals.

For readings taken at observation depth of $0.20 \mathrm{~m}$, the manually formed bunds showed the least shear strength on the day of bund formation, indicating that the manual bund formation did not impart sufficient strength to the bund, or that the bund was not sufficiently compacted by manual operation on the first day. The mechanically formed bunds showed an increasing trend in shear strength values. The bunds formed by the medium bund former exhibits higher values of shear strength 
throughout the observation period. By the third day, all the mechanically formed bunds showed values on par and more than those of manually formed bunds; a similar observation being obtained on the seventh day also. As depth of measurement increased to $40 \mathrm{~cm}$ bunds formed by medium bund former had highest values. At the observational depth of $60 \mathrm{~cm}$ almost all types of bunds, except those formed by the medium bund former showed on par values. The bunds formed by the medium bund former still exhibited the highest value.

This indicated that for the silty clay soils of Pullazhi kole, having clay content of 46.2 to $47.8 \%$, strong bunds could be formed using the medium bund former with a front cutting width of $900 \mathrm{~mm}$. The power source used is the $11.5 \mathrm{~kW}$ mini tractor, which could be a replacement to the power tiller, as the mini tractors offer more operator comfort and safety than the power tillers. Moreover, in Pullazhi kolepadavu, the lower strata of soil, below $40 \mathrm{~cm}$, have a lesser shear strength and heavier machinery cannot be used in these fields. Hence mini tractor is a feasible and comfortable alternative power source for the operator.

\section{Shear strength changes observed in bunds formed at Kolothumpadam kolepadavu}

Tables 5 to 7 show the changes in the values of shear strengths measured at different depths at the Kolothumpadam kolepadavu. The distribution of the shear strength over depth and time is shown in Figure 2.

At Kolothumpadam kolepadavu, the soils were silty clay and had a clay content ranging from 51.8 to $55.6 \%$. When shear strength was measured at depth of $0.20 \mathrm{~m}$, the maximum shear strength was observed for bunds formed by the big bund formers and those formed by the combination run (i.e., the bunds first formed using the big bund formers and these being overrun by the medium bund formers along their entire length). The values of shear strength for the manually formed bunds were the lowest. The same trend was observed throughout the period of observation, with the values being considerably less throughout.

The soil here had a higher percentage of clay compared to the earlier soil type; and the force applied by the labour during manual formation of bunds being less; lesser strength is imparted to the upper layers of the bund.

The same pattern of readings was seen for values of shear strength at the depth of $0.40 \mathrm{~m}$, and the bunds became stronger by the seventh day. The mechanically formed bunds were all on par in terms of strength.

At the depth of $0.60 \mathrm{~m}$, the shear strength at bunds formed mechanically with big bund former and the combination run showed the highest values; and the manually formed bunds were on par with the bunds formed by the medium bund former. Shear strength increased considerably in all cases and as time progresses, almost all the bunds were seen to have comparable strength values.

Shear strength changes observed in bunds formed at Athalur, Tavanur (non kole lands)

Trials at Tavanur fields were conducted using two power sources, viz., the $31.32 \mathrm{~kW}$ tractor and the $11.5 \mathrm{~kW}$ mini tractor. The soil here was sandy clay with a low clay content ranging from 11.5 to $13.8 \%$. The variations in shear strength values of the bunds formed are shown in Figures 3 and 4. 
Table.1 Sizes of bunds formed by the three models of the tractor operated bund formers

\begin{tabular}{|l|l|l|l|}
\hline \multirow{2}{*}{ Bund dimensions } & \multicolumn{3}{|c|}{ Model of bund former } \\
\hline Height - rear $(\mathrm{mm})$ & 150 & 150 & 250 \\
\hline Top width - rear $(\mathrm{mm})$ & 150 & 200 & 250 \\
\hline Bottom width - rear $(\mathrm{mm})$ & 250 & 350 & 400 \\
\hline
\end{tabular}

BF1 - Small bund former, with front cutting width $450 \mathrm{~mm}$ BF2 - Medium bund former with front cutting width $900 \mathrm{~mm}$ BF3 - big bund former with front cutting width $1150 \mathrm{~mm}$

Table. 2 Summary of changes in shear strength at a depth of $0.20 \mathrm{~m}$ at consecutive time intervals at Pullazhi kole

\begin{tabular}{|l|c|c|c|}
\hline Method of bund formation & Day 1 & Day 3 & Day 7 \\
\hline Manually formed & $4.34^{\mathrm{d}}$ & $7.81^{\mathrm{b}}$ & $24.31^{\mathrm{c}}$ \\
\hline Mechanically formed - Big & $25.18^{\mathrm{c}}$ & $32.99^{\mathrm{a}}$ & $37.34^{\mathrm{b}}$ \\
\hline Mechanically formed - Medium & $46.02^{\mathrm{a}}$ & $36.47^{\mathrm{a}}$ & $40.81^{\mathrm{ab}}$ \\
\hline Mechanically formed - Small & $34.73^{\mathrm{b}}$ & $33.00^{\mathrm{a}}$ & $46.02^{\mathrm{a}}$ \\
\hline
\end{tabular}

Table.3 Summary of changes in shear strength at a depth of $0.40 \mathrm{~m}$ at consecutive timeintervals at Pullazhi kole

\begin{tabular}{|l|}
\hline Method of bund formation \\
\hline Manually formed \\
\hline Mechanically formed - Big \\
\hline Mechanically formed - Medium \\
\hline Mechanically formed - Small \\
\hline
\end{tabular}

Table.4 Summary of changes in shear strength at a depth of $0.60 \mathrm{~m}$ at consecutive time intervals at Pullazhi kole

\begin{tabular}{|l|l|l|}
\hline Day 1 & Day 3 & Day 7 \\
\hline $31.26^{\mathrm{c}}$ & $33.86^{\mathrm{b}}$ & $48.62^{\mathrm{b}}$ \\
\hline $33.86^{\mathrm{c}}$ & $62.52^{\mathrm{a}}$ & $69.47^{\mathrm{a}}$ \\
\hline $75.54^{\mathrm{a}}$ & $70.33^{\mathrm{a}}$ & $76.41^{\mathrm{a}}$ \\
\hline $49.49^{\mathrm{b}}$ & $58.18^{\mathrm{a}}$ & $33.86^{\mathrm{c}}$ \\
\hline
\end{tabular}

\begin{tabular}{|l|}
\hline Method of bund formation \\
\hline Manually formed \\
\hline Mechanically formed - Big \\
\hline Mechanically formed - Medium \\
\hline Mechanically formed - Small \\
\hline
\end{tabular}

\begin{tabular}{|l|l|l|}
\hline Day 1 & Day 3 & Day 7 \\
\hline $14.76^{\mathrm{b}}$ & $17.36^{\mathrm{b}}$ & $20.84^{\mathrm{ab}}$ \\
\hline $16.50^{\mathrm{b}}$ & $19.10^{\mathrm{b}}$ & $19.97^{\mathrm{ab}}$ \\
\hline $47.76^{\mathrm{a}}$ & $42.55^{\mathrm{a}}$ & $23.44^{\mathrm{a}}$ \\
\hline $13.02^{\mathrm{b}}$ & $17.36^{\mathrm{b}}$ & $17.36^{\mathrm{b}}$ \\
\hline
\end{tabular}

Table.5 Summary of changes in shear strength at a depth of $0.20 \mathrm{~m}$ at consecutive intervals at Ponnani kole

\begin{tabular}{|l|c|c|c|}
\hline \begin{tabular}{l} 
Ponnani kole \\
\hline Method of bund formation
\end{tabular} & Day 1 & Day 3 & Day 7 \\
\hline Manually formed & $6.94^{\mathrm{c}}$ & $13.02^{\mathrm{c}}$ & $22.57^{\mathrm{c}}$ \\
\hline Mechanically formed - Big & $28.65^{\mathrm{a}}$ & $37.34^{\mathrm{a}}$ & $55.57^{\mathrm{a}}$ \\
\hline Mechanically formed - Medium & $22.57^{\mathrm{b}}$ & $27.78^{\mathrm{b}}$ & $39.94^{\mathrm{b}}$ \\
\hline Mechanically formed - Combination* & $27.78^{\mathrm{a}}$ & $35.60^{\mathrm{a}}$ & $59.05^{\mathrm{a}}$ \\
\hline
\end{tabular}

$*$ Combination $=$ Big bund former followed by medium bund former 
Table.6 Summary of changes in shear strength at a depth of $0.40 \mathrm{~cm}$ at consecutive intervals at Ponnani kole

\begin{tabular}{|l|}
\hline Method of bund formation \\
\hline Manually formed \\
\hline Mechanically formed - Big \\
\hline Mechanically formed - Medium \\
\hline Mechanically formed - Combination* \\
\hline
\end{tabular}

$*$ Combination $=$ Big bund former followed by medium bund former

\begin{tabular}{|l|l|l|}
\hline Day 1 & Day 3 & Day 7 \\
\hline $42.55^{\mathrm{b}}$ & $47.76^{\mathrm{c}}$ & $74.67^{\mathrm{b}}$ \\
\hline $65.99^{\mathrm{a}}$ & $77.28^{\mathrm{a}}$ & $85.09^{\mathrm{ab}}$ \\
\hline $49.49^{\mathrm{b}}$ & $56.44^{\mathrm{b}}$ & $79.88^{\mathrm{ab}}$ \\
\hline $70.33^{\mathrm{a}}$ & $81.62^{\mathrm{a}}$ & $86.83^{\mathrm{a}}$ \\
\hline
\end{tabular}

Table.7 Summary of changes in shear strength at a depth of $0.60 \mathrm{~m}$ at consecutive intervals at Ponnani kole

\begin{tabular}{|l|}
\hline Method of bund formation \\
\hline Manually formed \\
\hline Mechanically formed - Big \\
\hline Mechanically formed - Medium \\
\hline Mechanically formed - Combination* \\
\hline
\end{tabular}

$*$ Combination $=$ Big bund former followed by medium bund former

\begin{tabular}{|l|l|l|}
\hline Day 1 & Day 3 & Day 7 \\
\hline $72.07^{\mathrm{b}}$ & $77.28^{\mathrm{b}}$ & $108.54^{\mathrm{a}}$ \\
\hline $82.49^{\mathrm{a}}$ & $98.12^{\mathrm{a}}$ & $108.54^{\mathrm{a}}$ \\
\hline $70.33^{\mathrm{b}}$ & $88.57^{\mathrm{ab}}$ & $100.72^{\mathrm{a}}$ \\
\hline $80.75^{\mathrm{a}}$ & $100.72^{\mathrm{a}}$ & $102.46^{\mathrm{a}}$ \\
\hline
\end{tabular}

Table.8 Summary of changes in shear strength at a depth of $0.20 \mathrm{~m}$ at consecutive intervals at Tavanur using $31.32 \mathrm{~kW}$ tractor

\begin{tabular}{|l|}
\hline Method of bund formation \\
\hline Manually formed \\
\hline Mechanically formed - Big \\
\hline Mechanically formed - Medium \\
\hline Mechanically formed - Small \\
\hline Mechanically formed - Combination* \\
\hline
\end{tabular}

\begin{tabular}{|c|c|c|}
\hline Day 1 & Day 3 & Day 7 \\
\hline $9.55^{\mathrm{c}}$ & $13.02^{\mathrm{a}}$ & $17.36^{\mathrm{a}}$ \\
\hline $15.63^{\mathrm{ab}}$ & $9.55^{\mathrm{a}}$ & $10.42^{\mathrm{b}}$ \\
\hline $13.89^{\mathrm{bc}}$ & $9.55^{\mathrm{a}}$ & $8.68^{\mathrm{b}}$ \\
\hline $10.42^{\mathrm{c}}$ & $9.55^{\mathrm{a}}$ & $6.94^{\mathrm{b}}$ \\
\hline $19.10^{\mathrm{a}}$ & $12.16^{\mathrm{a}}$ & $11.29^{\mathrm{b}}$ \\
\hline
\end{tabular}

$*$ Combination $=$ Big bund former followed by medium bund former

Table.9 Summary of changes in shear strength at a depth of $0.40 \mathrm{~m}$ at consecutive intervals at Tavanur using $31.32 \mathrm{~kW}$ tractor

\begin{tabular}{l}
\hline Method of bund formation \\
\hline Manually formed \\
\hline Mechanically formed - Big \\
\hline Mechanically formed - Medium \\
\hline Mechanically formed - Small \\
\hline Mechanically formed - Combination*
\end{tabular}

\begin{tabular}{|c|c|c|}
\hline Day 1 & Day 3 & Day 7 \\
\hline $31.26^{c}$ & $37.34^{c}$ & $46.02^{b}$ \\
\hline $68.60^{b}$ & $63.39^{b}$ & $65.99^{a}$ \\
\hline $75.54^{a b}$ & $76.41^{a}$ & $70.33^{a}$ \\
\hline $77.28^{a b}$ & $71.20^{b}$ & $62.52^{a}$ \\
\hline $79.01^{a}$ & $64.26^{b}$ & $64.25^{a}$ \\
\hline
\end{tabular}

*Combination $=$ Big bund former followed by medium bund former 
Table.10 Summary of changes in shear strength at a depth of $0.60 \mathrm{~m}$ at consecutive intervals at Tavanur using $31.32 \mathrm{~kW}$ tractor

\begin{tabular}{|l|}
\hline Method of bund formation \\
\hline Manually formed \\
\hline Mechanically formed - Big \\
\hline Mechanically formed - Medium \\
\hline Mechanically formed - Small \\
\hline Mechanically formed - Combination* \\
\hline
\end{tabular}

\begin{tabular}{|l|l|l|}
\hline Day 1 & Day 3 & Day 7 \\
\hline $43.42^{\mathrm{b}}$ & $49.49^{\mathrm{a}}$ & $56.44^{\mathrm{a}}$ \\
\hline $49.49^{\mathrm{ab}}$ & $42.55^{\mathrm{b}}$ & $44.28^{\mathrm{b}}$ \\
\hline $53.83^{\mathrm{a}}$ & $52.97^{\mathrm{a}}$ & $62.52^{\mathrm{a}}$ \\
\hline $48.62^{\mathrm{ab}}$ & $38.21^{\mathrm{b}}$ & $44.28^{\mathrm{b}}$ \\
\hline $47.76^{\mathrm{ab}}$ & $38.21^{\mathrm{b}}$ & $39.94^{\mathrm{b}}$ \\
\hline
\end{tabular}

*Combination $=$ Big bund former followed by medium bund former

Table.11 Summary of changes in shear strength at a depth of $0.20 \mathrm{~m}$ at consecutive intervals at Tavanur using $11.5 \mathrm{~kW}$ mini tractor

\begin{tabular}{|l|l|l|l|}
\hline Method of bund formation & Day 1 & Day 3 & Day 7 \\
\hline Manually formed & $9.55^{\mathrm{b}}$ & $13.02^{\mathrm{b}}$ & $17.36^{\mathrm{c}}$ \\
\hline Mechanically formed - Medium & $18.23^{\mathrm{a}}$ & $20.84^{\mathrm{a}}$ & $31.26^{\mathrm{a}}$ \\
\hline Mechanically formed - Small & $12.15^{\mathrm{b}}$ & $17.36^{\mathrm{ab}}$ & $26.05^{\mathrm{b}}$ \\
\hline
\end{tabular}

Table.12 Summary of changes in shear strength at a depth of $0.40 \mathrm{~m}$ at consecutive intervals at Tavanur using $11.5 \mathrm{~kW}$ mini tractor

\begin{tabular}{|l|l|l|l|}
\hline Method of bund formation & Day 1 & Day 3 & Day 7 \\
\hline Manually formed & $31.26^{\mathrm{a}}$ & $37.34^{\mathrm{a}}$ & $46.02^{\mathrm{a}}$ \\
\hline Mechanically formed - Medium & $26.05^{\mathrm{b}}$ & $28.65^{\mathrm{b}}$ & $37.34^{\mathrm{b}}$ \\
\hline Mechanically formed - Small & $18.23^{\mathrm{c}}$ & $21.71^{\mathrm{c}}$ & $31.26^{\mathrm{c}}$ \\
\hline
\end{tabular}

Table.13 Summary of changes in shear strength at a depth of $0.60 \mathrm{~m}$ at consecutive intervals at Tavanur using $11.5 \mathrm{~kW}$ mini tractor

\begin{tabular}{|l|l|l|l|}
\hline Method of bund formation & Day 1 & Day 3 & Day 7 \\
\hline Manually formed & $43.41^{\mathrm{a}}$ & $49.49^{\mathrm{a}}$ & $56.44^{\mathrm{a}}$ \\
\hline Mechanically formed - Medium & $40.81^{\mathrm{a}}$ & $47.76^{\mathrm{a}}$ & $59.91^{\mathrm{a}}$ \\
\hline Mechanically formed - Small & $32.13^{\mathrm{b}}$ & $33.86^{\mathrm{b}}$ & $46.02^{\mathrm{b}}$ \\
\hline
\end{tabular}


Fig.1 Shear strength of different bunds formed at Pullazhi kolepadavu

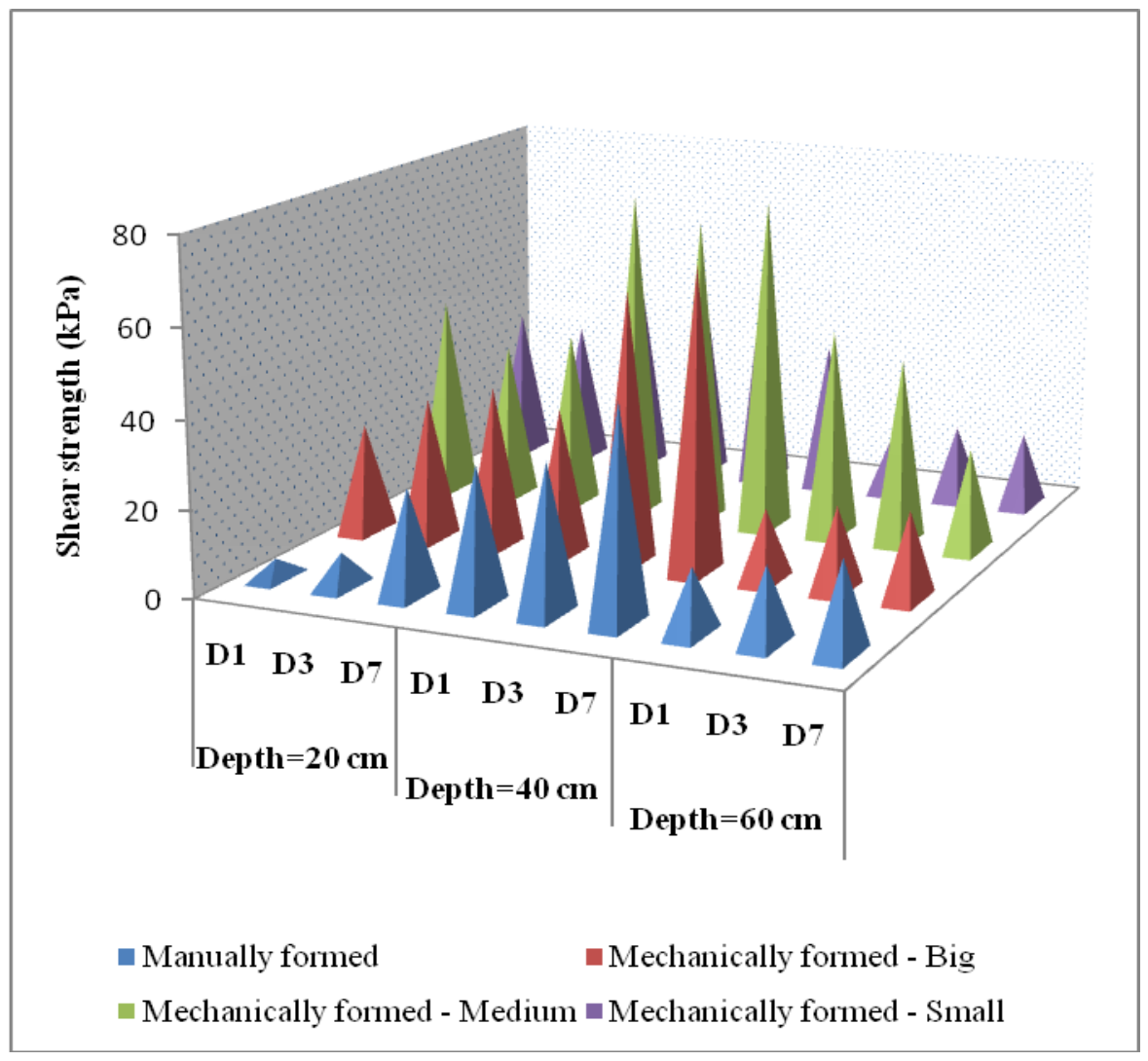

Fig.2 Shear strength of different bunds formed at Kolothumpadam kolepadavu

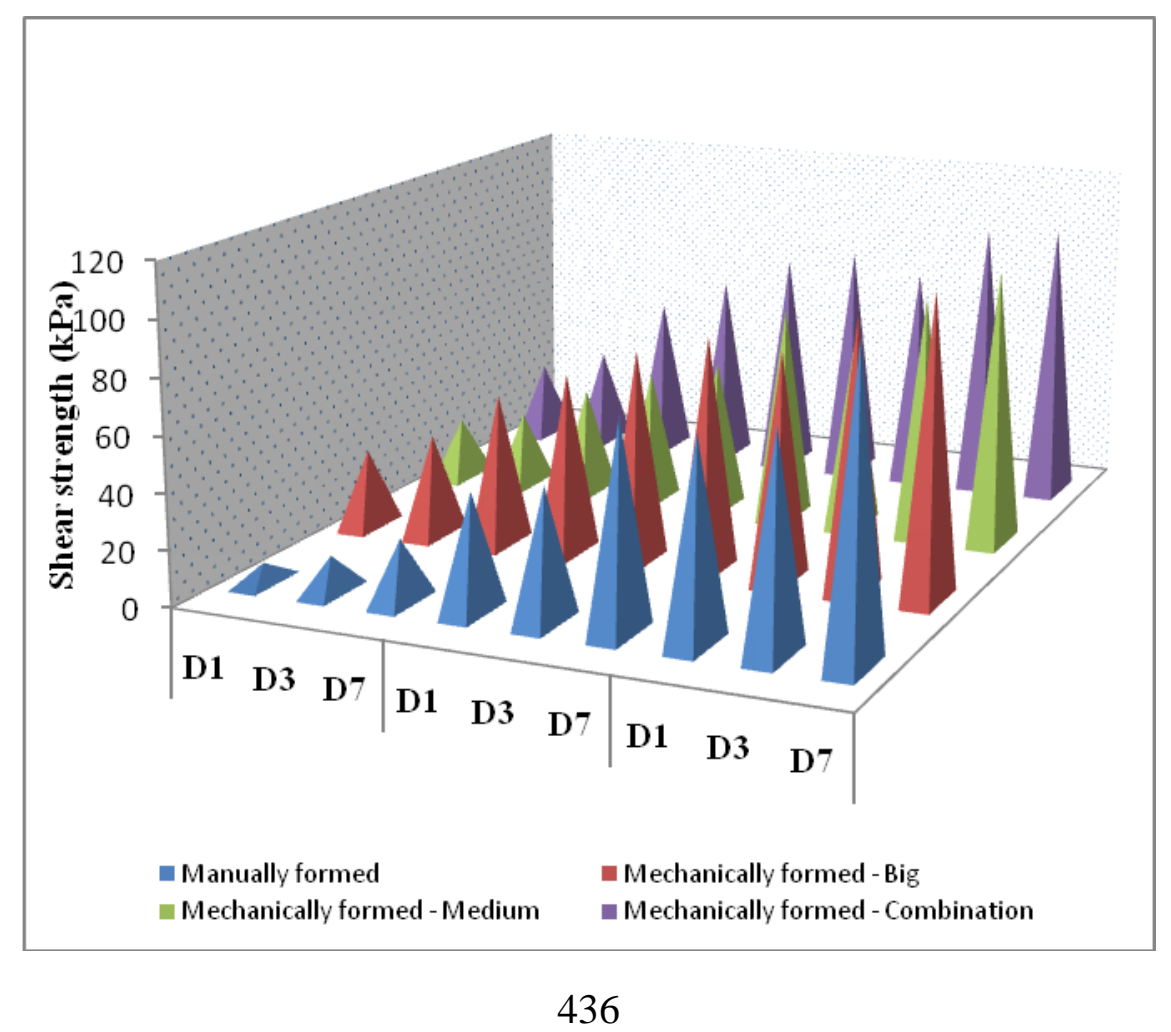


Fig.3 Shear strength of different bunds formed at Athalur, using $31.32 \mathrm{~kW}$ tractor

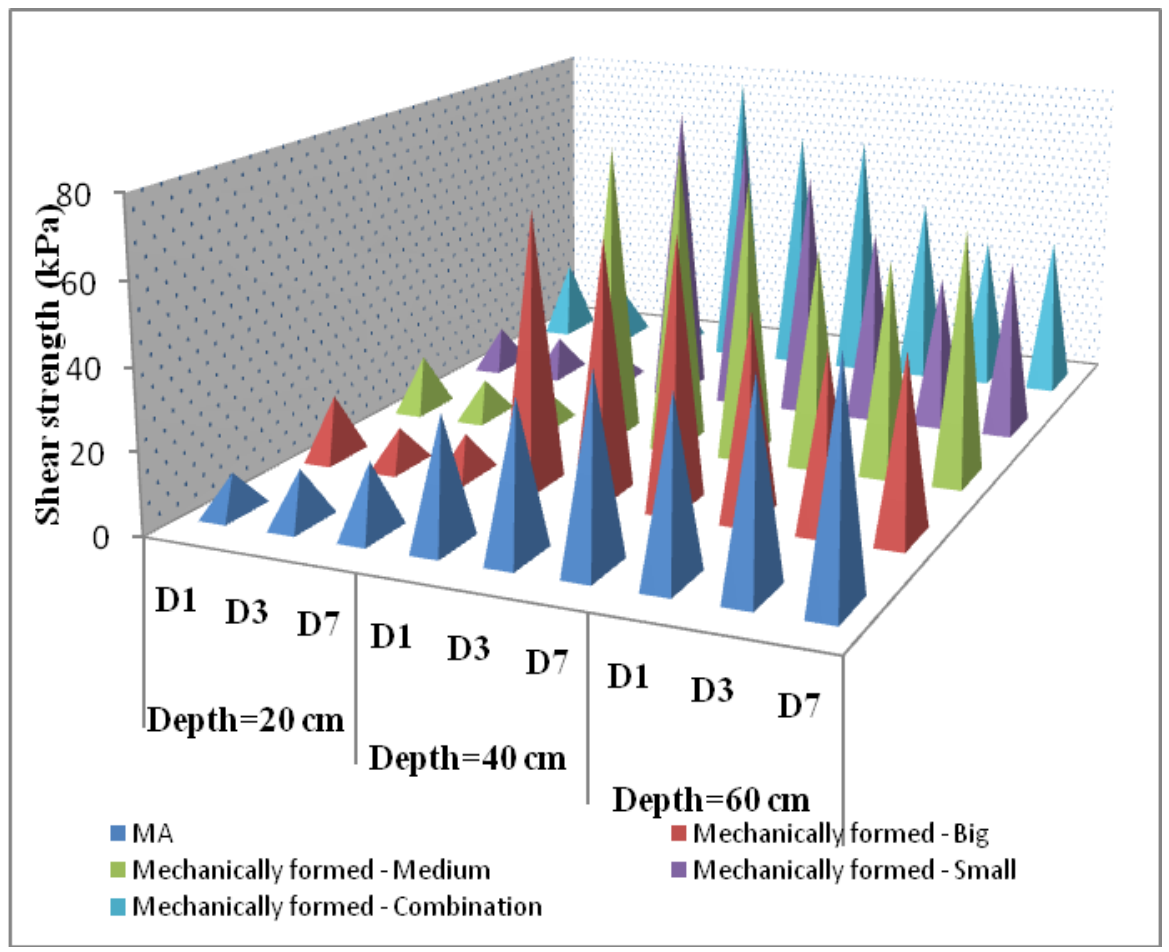

Fig.4 Shear strength of different bunds formed at Athalur, using $11.5 \mathrm{~kW}$ mini tractor

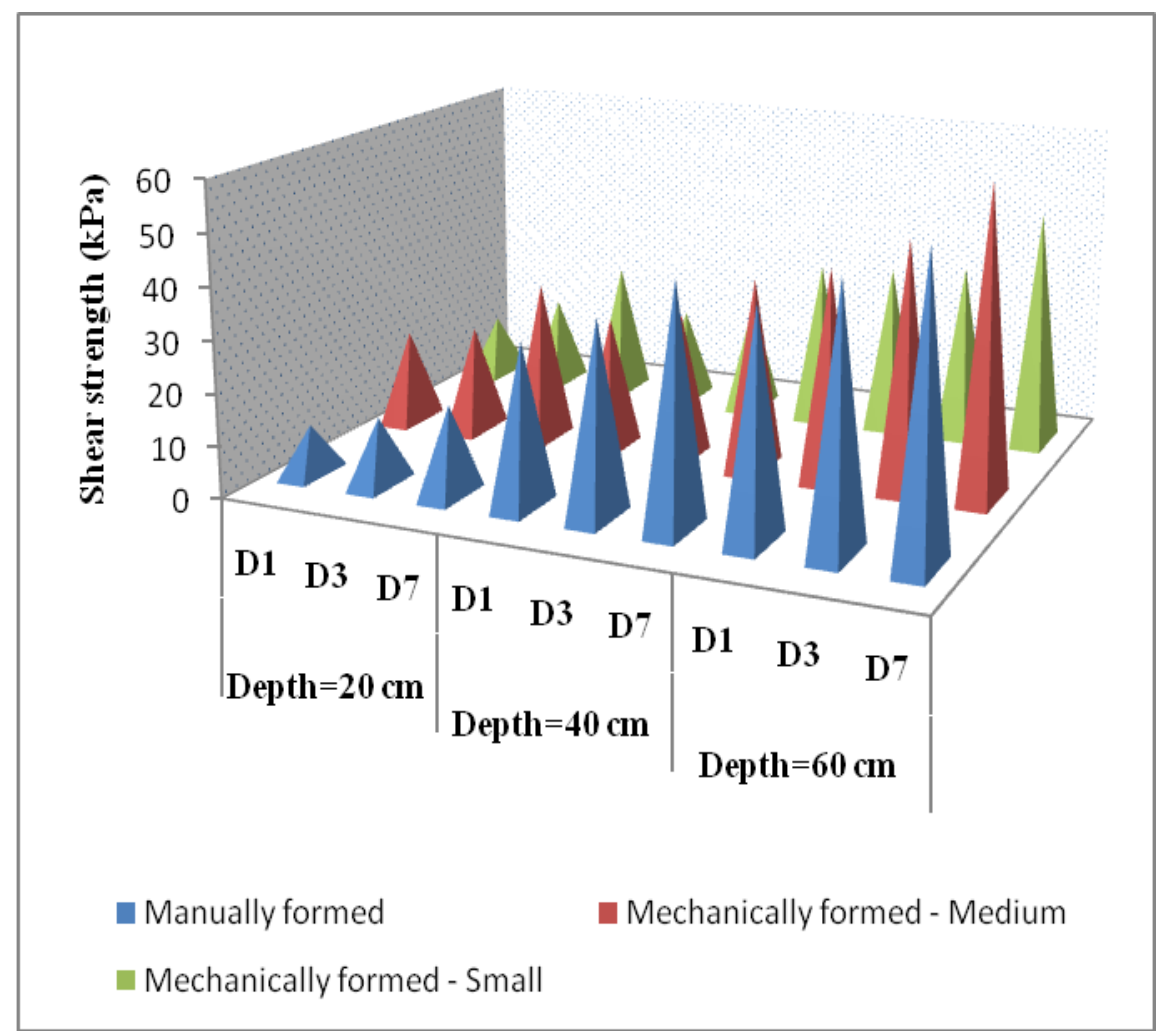


When the $31.32 \mathrm{~kW}$ tractor was used as the power source, it was seen that the shear strength at the depth of $0.20 \mathrm{~m}$ on the day of bund formation was highest for the bunds formed by the combination run, which was comparable with the bunds formed using big bund former. This was followed by the bunds of medium bund former and small bund former. The manually formed bunds had on par strength with the small bund former bunds. Their values were the lowest. This was an indication of the lesser compaction given to the soil while bunds are formed using these methods. As the size of the manually formed bunds was higher at this test location, by the seventh day these bunds showed a higher value for shear strength and the observations are summarised in Table 8.

Table 9 gives the shear strength values at the depth of $0.4 \mathrm{~m}$ using the $31.32 \mathrm{~kW}$ tractor. On the first day, at $0.40 \mathrm{~m}$, the shear strengths of the bunds decreased in the order as bunds formed mechanically using the combination run, (small bund former, medium bund former), followed by big bund former and then the manually formed bunds.

By the third day, a pairing of the bunds formed by the big bund former and the combination run, and the small and medium bund formers was observed. By the seventh day of observation, all the mechanically formed bunds were on par.

For the measurements taken at $0.60 \mathrm{~m}$ depth, as seen from table 10, the first day's observations showed that the bunds formed by the big, small and the combination run had similar distribution of the shear strength, These values were not very different from the strength of the manually formed bunds also. However the bunds formed by the medium bund former had higher values. The ordering of the strength of bunds changed to bunds formed by (manual, medium former) and (big former, small former, combination run) on the third and seventh day.

When the bunds were formed using the 11.5 $\mathrm{kW}$ mini tractor as the power source, the strength of the mechanically formed bund using the medium bund former was found to be the highest throughout the period of observation, at depth of $0.20 \mathrm{~m}$. This indicated better compaction of soil by this model. By the seventh day after bund formation, the ordering of strength was mechanically formed medium bund, mechanically formed small bund and manually formed bund. At depth of $0.40 \mathrm{~m}$, the strength noted for the manually formed bunds was the highest throughout the period of observation, followed by the mechanically formed bunds using the medium and small formers respectively.

For the measurements taken at the depth of $0.60 \mathrm{~m}$, the strength of manually formed, and mechanically formed bunds using medium bund former were on par. The observations are illustrated in tables 11 to 13.

The farmers' practice at the Athalur non kole paddy fields are large bunds having top width ranging from $40 \mathrm{~cm}$ to $50 \mathrm{~cm}$ and height up to $60 \mathrm{~cm}$. Hence the bund formers developed could be used only for drawing new bunds in the field and not for strengthening the existing bunds, which is generally practiced by farmers. The increased shear strength offered by the manual bunds at greater depths is due to the fact that the lower layers constitute compacted soil from previous seasons and hence are more dense and strong. Only at the initial depth of measurement $(0.2 \mathrm{~m})$ could the mechanically formed bunds provide better strength characteristics, as the soil was compressed more when it passed through the implement. The manual operation using a spade could not compact the top layer to the same extent. 
The three types of bund formers were assessed at the different test locations. It was found that the medium bund former gave stronger bunds at Pullazhi kolepadavu while at the Kolothumpadam kolepadavu, the big bund formers and the combination run of formers, by operating the medium bund former over bunds first formed by big bund formers, formed the strongest bunds. At Athalur, Tavanur, the field was non kole, the soil was sandy clay and the prevalent practice was to construct large sized bunds manually. Here, the possibility of drawing new bunds using the mechanical bund formers in the fields, for demarcation and water management, was assessed. It was observed that the mechanical bund formers could form sufficiently strong bunds using both mini tractors and conventional tractors. Hence the mechanical bund formers could be used in these areas for formation of new field bunds.

\section{Acknowledgment}

The first author acknowledges the technical and financial assistance received from Kerala Agricultural University, for the study as a part of her $\mathrm{Ph}$. D programme. The authors are grateful to the Dean and Head of Department (FPME), KCAET, Tavanur for providing facilities to undertake the study.

\section{References}

ASTM D2573 / D2573M-15e1, Standard Test Method for Field Vane Shear Test in Saturated Fine-Grained Soils, ASTM
International, West Conshohocken, PA, 2015, www.astm.org

Jayan P. R. and Sathyanathan, N.2010. Overview of farming practices in water logged areas of Kerala, India. Int. J. Agric. Biol. Eng. 3(4): 1-16.

Kepner, R.A., Bainer, R. and Barger, E.L., 1990. Principles of farm machinery (4th Ed,), Avi Pub. Co., Westport, Connecticut.

Leema T. G. 2015. An economic analysis of Kole cultivation in Kerala with special reference to Thrissur District.Ph. D (Economics) thesis, Mahatma Gandhi University, Kottayam, 269p.

O'Sullivan, M.F. and Robertson, E.A.G., 1996. Critical state parameters from intact samples of two agricultural topsoils. Soil Tillage Res., 39(3-4), pp.161-173.

Roy, S. and Dass, G., 2014. Statistical models for the prediction of shear strength parameters at Sirsa, India. Int. J. Civil Struct. Eng. 4(4): 483-498.

Smith, V. T. (1966). The development of a modified soil vane shear. Master's Thesis, University of Missouri at Rolla, USA, 5727, 72p. Available: http://scholarsmine.mst.edu/masters_the ses/5727

Tada, A. 1987. Bearing capacity. In: Tabuchi, T., Iwata, S., Hasegawa, S., Woodhead, T. and Maurer, E. (eds.), Physical Measurements in Flooded Soils - The Japanese Methodologies. IRRI, Los Banos, Philippines, pp. 55-61.

\section{How to cite this article:}

Suma Nair and Ramachandran, V.R. 2018. How Mechanical Bund Formation Affects the Shear Strength of Bunds: A Study in Paddy Wetlands. Int.J.Curr.Microbiol.App.Sci. 7(11): 429-439. doi: https://doi.org/10.20546/ijcmas.2018.711.050 